\title{
Erratum zum Beitrag: Veränderungsprozesse wirkungsvoll vermitteln
}

\section{Steffen Rinas}

Springer Fachmedien Wiesbaden GmbH 2014

Erratum zu: Controlling \& Management Review Sonderheft 2/2014 (Ausgabe 8/2014), S. 74-77

DOI: 10.1365/s12176-014-0967-7

In der Online-Version des Originalartikels war der Name des Autors Steffen Rinas falsch. Wir bitten dies zu entschuldigen. 